Research Article

\title{
The Integrated Hydropower Sustainability Assessment in Tajikistan: A Case Study of Rogun Hydropower Plant
}

\author{
Zhao Xu $\mathbb{D},{ }^{1}$ Yumin Niu $\left(\mathbb{D},{ }^{1}\right.$ Yangze Liang $\mathbb{D},{ }^{1}$ Zhigang $L i\left(\mathbb{D},{ }^{1}\right.$ and Atoev Iftikhor $\mathbb{D}^{2}$ \\ ${ }^{1}$ Department of Civil Engineering, Southeast University, Nanjing 210096, China \\ ${ }^{2}$ State Committee on Investment and State Property Management, Dushanbe, Tajikistan
}

Correspondence should be addressed to Zhao Xu; xuzhao@seu.edu.cn

Received 20 May 2020; Revised 15 August 2020; Accepted 26 August 2020; Published 10 September 2020

Academic Editor: Dong Zhao

Copyright $($ C 2020 Zhao Xu et al. This is an open access article distributed under the Creative Commons Attribution License, which permits unrestricted use, distribution, and reproduction in any medium, provided the original work is properly cited.

\begin{abstract}
Tajikistan has formulated the strategy to rejuvenate the country through hydropower. The Rogun hydropower plant (HPP) is designed as the highest hydropower station, while its sustainability is also questioned due to a lack of comprehensive sustainability evaluation. Considering that the external environment of Rogun HPP is complex and changeable, its sustainable performance will be fragile and inconstant. To comprehensively assess the sustainable performance, an integrated evaluation framework, covering the current and dynamic sustainable performance, is urgently established. Therefore, this paper firstly explored the hydropower sustainability assessment indicators which can conform to Tajikistan's situations and further examined the current sustainable performance of Rogun HPP. The case study found that Rogun HPP's current financial viability, involuntary resettlement, the measures to prevent corruption, and information disclosure were seriously deficient. The SWOT analysis indicated the external factors, such as the Belt and Road Initiative, improving business environment, and easing geopolitical disputes, can eliminate weaknesses and improve the sustainable performance of Rogun HPP. At the same time, tight fiscal allocations and economic downturns will have negative influences on the sustainable performance. The integrated evaluation tool established in this paper can not only evaluate the current sustainable performance but also consider the impact of external factors on sustainable performance from a dynamic perspective. This paper contributes to the current knowledge system by establishing the hydropower sustainability assessment system which is suitable for Tajikistan's conditions. Moreover, the results are informative for the decision-makers to have a better understanding of Rogun HPP's current strengths and weaknesses, valuable opportunities, and potential threats.
\end{abstract}

\section{Introduction}

Hydropower remains the world's largest renewable energy source [1-3]. About $85 \%$ of global renewable electricity is generated in hydropower facilities [4]. Hydropower is widely considered to have mature technology, extraordinary durability and reliability, higher efficiency, obvious cost advantages, and lower maintenance costs than other forms of electricity generation $[5,6]$. At the same time, economists believe that hydropower dams can create jobs and boost economic growth. The urgent demand for clean energy, cheap electricity, and potential profits has directly contributed to the prosperity of hydropower in developing countries. Tajikistan has also formulated an ambitious plan for rejuvenating the country with hydropower and plans to achieve energy independence by 2030 . The construction of new HPPs and the modernization of existing power stations are Tajikistan's strategic priorities.

The benefits of hydropower, such as considerable power generation efficiency and high multiplier effects, are significant, but they are often accompanied by irreversible environmental and social damage $[4,7]$. Dam construction, especially for large dams, focuses on energy supply and economic development, while social and environmental damage is often overlooked or underestimated $[8,9]$. During the development process, the hydropower project exposed historical and cultural damage, reduced biodiversity, and ecological imbalances $[10,11]$. Besides, hydropower development is also accompanied by displacement [5, 12, 13], more susceptible to corruption [14], and unfair distribution 
of benefits $[15,16]$. Dams can also have a negative economic impact. The aging of the dam brings a decline in operating efficiency and increased safety risks, so the dam owner has to bear expensive maintenance costs [17]. Because the cost of repairing a small dam is three times the cost of demolition, some dam owners and managers choose to demolish the dam instead of performing expensive repairs or upgrades [18]. By 2019, Europe has demolished 3,500 dams [19]. The clean, low-carbon hydropower sources may have unsustainable effects. Improper planning of hydropower projects will have devastating consequences for society and the environment [20-22]. Sustainable development depends not only on how the potential change is selected but also how they are implemented [17]. With increasing awareness of environmental protection and human rights, people are reexamining hydropower and its role in national development. In 2000, the World Commission on Dams (WCD) issued a landmark report calling on hydropower development to focus on sustainability. Since then, the "low impact hydropower" certification, "green hydropower," and "hydropower sustainable development specification" certification have been proposed by the United States, Switzerland, and the International Hydropower Association (IHA), respectively. Hydropower development has evolved from simply meeting the requirements for acceptable hydropower to recognizing the core principles of sustainable development and striving to reduce or even eliminate negative economic, environmental, and social impacts [23].

At present, the efficient, equitable, and sustainable management of water resource is vital for Tajikistan. Tajikistan has invested in large-scale hydropower projects to fill the huge electricity gap. Tajikistan has abundant water resources with more than 900 rivers, 1300 lakes, and many mountain glaciers [24]. According to statistics, $60 \%$ of water resources in Central Asian countries are formed in the territory of Tajikistan, which can be used sustainably $[25,26]$. Tajikistan has invested in large-scale hydropower projects. Among these, the Rogun HPP is the most representative project, which is expected to generate an average of 17 billion kilowatt hours of electricity annually. When Rogun is built, Tajikistan will be the largest supplier of relatively cheap and environmentally friendly electricity, which will contribute to the growth of the economy and regional influence. However, the external tension in Central Asia on water resource disputes and the internal backward economy have made it difficult for sustainability development. The Rogun project is postponed due to some issues, which have undesirable impacts on the economy of Tajikistan. Meanwhile, the sustainability of the Rogun project has raised doubts among experts and scholars. Hence, it is necessary to explore the sustainability of Rogun HPP, which will have a better understanding of Rogun HPP and promote the sustainable development of hydropower.

It should be mentioned that the sustainable performance will change due to fluctuating external conditions. The existing sustainable evaluation often only focuses on sustainable performance at a certain moment, which leads to a static and one-side result. It is necessary to build an evaluation model that integrates current performance with potential future changes. Sustainability evaluation that combines static and dynamic perspectives can provide more informative reports and reveal more comprehensive advantages and challenges. Besides, the hydropower sustainability assessment focusing on Tajikistan is a research gap. The existing international hydropower sustainability assessment tool, such as the Hydropower Sustainability Guidelines and Hydropower Sustainability Assessment Protocol (HSAP), Low Impact Hydropower Certification scheme, and the Green Hydropower Certification scheme, cannot be directly employed to assess the sustainable performance of hydropower in Tajikistan. Firstly, due to the different social, cultural, and political conditions in different countries and regions, conducting assessments in an international context is particularly challenging. To increase the applicability, the abovementioned hydropower sustainable evaluation standards are mostly guiding and principled. However, hydropower projects are almost always site-specific in terms of scale, management, cost, and benefits, which indicates that it is difficult to assess the social and environmental impact of a hydropower project with a unified evaluation system [4]. Secondly, the existing standards do not fully reflect the prominent issues that Tajikistan may face in the sustainable development of hydropower, such as transboundary water governance, financing, and corruption. The sustainable assessment tool for hydropower projects that fits the national conditions is a prerequisite for accurate results of evaluation. Therefore, the Tajikistanspecific evaluation criteria should be established to check hydropower sustainability.

The objective of this paper is to explore the sustainability performance of Rogun HPP using an integrated method from the perspective of dynamic development. This paper first provides the basic situation of Tajikistan's power supply and sustainable development and then establishes a checklist of sustainable hydropower assessment that is suitable for Tajikistan's national conditions. Based on this, a systematic review of Rogun HPP covering economic, environmental, and social aspects and risk management will be conducted. Finally, based on the SWOT, this article discusses potential opportunities and threats for the sustainable development of Rogun HPP from the dynamic perspective. As a result, this research will provide insight into the current sustainable performance of the Rogun HPP and potential change in the future.

\section{Hydropower Ambitions and Sustainable Development in Tajikistan}

2.1. Underutilized Water Resources. As the heart of water reserves in Central Asia, Tajikistan is rich in lakes and reservoirs and its water surface is approximately $1005 \mathrm{~km}^{2}$ of which the top 22 lakes in Tajikistan cover an area of about $625 \mathrm{~km}^{2}$. According to statistics, $60 \%$ of water resources in Central Asian countries are formed in the territory of Tajikistan, which can be used sustainably [25, 26]. However, the lack of reservoirs and hydropower plants in Tajikistan leads to underutilization of renewable energy resources and a series of problems such as electricity shortage in winter 
[27], which greatly increase the difficulties in the development of the economy.

In terms of potential hydropower reserves, Tajikistan ranks 8th in the world behind China, Russia, the United States, Brazil, Zaire, India, and Canada. Specifically, it ranks 1st and 2nd around the world in terms of hydropower generation capacity per square kilometer $\left(36,699,000 \mathrm{kWh} / \mathrm{km}^{2} /\right.$ year $)$ and per capita $(65,900 \mathrm{kWh} /$ person/year). Besides, it is expected that Tajikistan's hydropower potential can provide sufficient energy security for Central Asia, at 527 billion (kWh/year) equivalent to three times the current electricity consumption in Central Asia [28]. Therefore, the effective development of hydropower in Tajikistan not only plays an important role in the domestic energy security but also affects the economic development and energy distribution of Central Asia.

However, hydropower in Tajikistan is not fully utilized. In 2018, its total installed capacity of HPPs was only 29th in the world with $5795 \mathrm{MW}$, and its power generation capacity was only 30th in the world with 17.7 TWh. Although Tajikistan continues to build large hydropower projects such as the Rogun HPP and ranks 6th in the world with the newly installed hydropower capacity of $605 \mathrm{MW}$, as shown in Figure 1, such installed capacity and power generation scale are still far from sufficient for Tajikistan and Central Asia [29].

2.2. Electricity Shortages. Tajikistan's energy supply mainly comes from hydropower, coal, and oil. Although hydropower generation has not increased significantly since the 1990s, its consumption is much greater than any other type of energy consumption, remaining as high as at $60 \%$ after 2000 and reaching a maximum of $75.8 \%$ in 2010 , as shown in Figure 2 [30].

Today, over 95-99\% of Tajikistan's electricity generation is based on hydropower, while only $5 \%$ of this hydropower potential of about 4,412.7 MW has been being used. The total installed capacity of Tajikistan's hydropower in 2018 was $5,795 \mathrm{MW}$. Fortunately, the installed capacity of the newly built Logon HPP in 2019 reaches 3,600 MW, which may greatly increase the hydropower capacity of Tajikistan and Central Asia [29].

Nevertheless, Tajikistan's power production is still insufficient to meet domestic demand throughout the year. There are two reasons for this issue. On the one hand, the power equipment currently used in Tajikistan is a product leftover from the Soviet era. The equipment is severely aging, with poor performance and safety levels so that the loss rate in Tajikistan's power grid is as high as about 15\%. For example, Nurek HPP, which accounts for about $70 \%$ of Tajikistan's total annual energy demand, has an installed capacity of more than $3,000 \mathrm{MW}$ and has an operating efficiency of only $77 \%$ since its commissioning in 1972 [31]. On the other hand, seasonal differences in Tajikistan's power system are so significant that $70 \%$ of its residents suffer from severe power shortages during the winter despite Tajikistan can export a large amount of electricity to other Central Asian countries. This is because that the average river flow in Tajikistan during the severe winter period (December to March of the following year) is only $25 \%$ of the annual

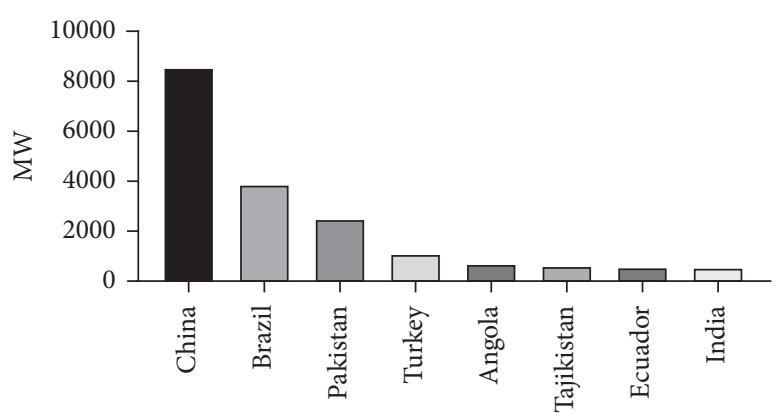

FIgURE 1: Newly installed capacity by the country, 2018.

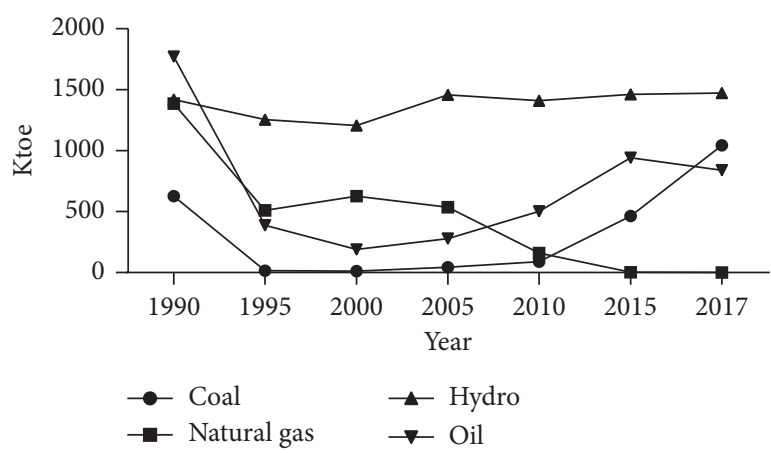

Figure 2: Total final consumption (TFC) by source, Tajikistan 1990-2017.

average flow, with its power shortage in autumn and winter accounting 3 to 3.5 billion kWh [32].

In the past decade, Tajikistan has a population growth of $53.4 \%$ to 9.53 million people, and a GDP growth of $46 \%$ to 7.523 billion, as one of the fastest-growing countries in the CIS. The rapid increase in population and economic scale may force Tajikistan to develop infrastructure, ensure energy security, and respond to public needs.

2.3. Hydropower Strategy. For Tajikistan, energy security after the collapse of the Soviet Union is a serious issue that needs to be solved urgently. In particular, unbalanced energy production capacity may restrict the improvement of people's living standards and industrial development. Therefore, how to obtain sustainable energy support, especially hydropower, can be an important national policy, which may promote domestic industries, expand the rural nonagricultural sectors, and accelerate sustainable development in Tajikistan.

Within the Sustainable Energy for All framework, Tajikistan released an assessment report, pointing out that by 2030, 5.6 million people living in rural areas of Tajikistan should be guaranteed access to regular and reliable electricity in the energy supply aspect, and in terms of energy efficiency, reducing energy losses up to $10 \%$ in power grids [33].

To achieve the above goals and realize energy independence, Tajikistan has invested in large-scale hydropower projects and power transmission network projects. Currently, 12 public energy projects with a total investment of 16.1 billion TJS (about $\$ 1.6$ billion) are under implementation. The 
most representative is Rogun HPP and Central Asia-South Asia Electricity Transmission and Trade Project (CASA1000). This is based on the consideration of increasing electricity generation and electricity import and export, respectively, so that Tajikistan may avoid the crisis of energy shortage even in the winter.

The Rogun HPP is expected to generate an average of 17 billion kWh annually, which will increase Tajikistan's electricity generation by at least 50\%. Meanwhile, CASA1000 may facilitate the exporting of surplus power energy from Kyrgyzstan and Tajikistan to Pakistan through Afghanistan by building up a power transmission line [34]. Hence, it is necessary to study the development of these projects and explore its sustainability. This will gain insight into project sustainability and promote the development of Tajikistan.

2.4. Sustainable Hydropower. Thousands of dams are being demolished in developed countries. In contrast, developing countries that are plagued by power shortages are speeding up dam construction [8]. Large hydropower infrastructure has the characteristics of a long construction period, large capital requirements, and wide-ranging scope. Therefore, once the project is not properly planned, it may have a significant negative effect on the economy, society, and ecology.

To reduce adverse effects, hydropower development must adhere to the principle of sustainable development [35]. The definition of sustainability based on the triple bottom line principle is widely adopted in studies related to sustainable development [36]. Sustainable hydropower has enormous potential to contribute to global sustainability goals. The objective to make energy systems sustainable has become a crucial policy-making priority. Inevitably, the government of Tajikistan faces the same challenges. Tajikistan, as a part of the international community, is also striving to achieve the goal of "a decade of sustainable energy for all" announced by the United Nations General Assembly in 2014-2024. The core goal of energy sustainable development is to ensure the supply of secure, sustainable, and affordable electricity [36]. Besides, with the public's concern about safety and environment, the environmental and social impacts of the project have become crucial factors affecting the success of the project [37].

Tajikistan faces many serious problems to achieve sustainable development of hydropower. The first is that the main rivers in Tajikistan are transboundary rivers and are upstream countries, which means that Tajikistan will affect downstream water-consuming countries when hydropower is generated. Also, no viable benefit distribution mechanism has been formed among Central Asian countries. This is an urgent issue for the sustainable development of Tajikistan's hydropower projects. The former Uzbekistan president was against the construction of Rogun HPP and argued this project will change the runoff pattern of the Amu Darya river, resulting in water shortage for irrigation in summer [38]. The opposition is not only due to the environmental issue, but also for political and economic considerations. Last but not least, it is also difficult for the government of Tajikistan to fully self-fund the cost of large-scale hydropower infrastructure. The World Bank also expressed concerns about Tajikistan's financing methods [39].

\section{Integrated Model of Hydropower Sustainability Assessment}

3.1. Conceptual Framework of the Integrated Hydropower Sustainability Assessment. The Checklist is a simple and practical evaluation tool [40]. Each hydropower project can choose appropriate indicators based on the project's unique natural resource issues and stakeholder priorities. It should be noted that the HPPs' sustainable evaluation, which is based on a checklist or MCDA, often only considers the impacts of the internal factors on sustainability. However, external factors are ignored. Due to the characteristics of a long construction period and capitalintensive nature, the sustainability performance of HPPs is easily affected by external factors such as macroeconomics and policies. In addition, the sustainability assessment that takes into account internal and external factors conduces comprehensively understand the current sustainable performance and possible changes in the future. The sustainable evaluation of HPPs should not only evaluate the current sustainable performance, but also consider the possible impact of external factors on the sustainable performance. Considering that SWOT analysis can integrate the internal or external factors of a project or enterprise, SWOT analysis was employed to comprehensively evaluate the sustainability of the project. In summary, the conceptual framework of this article is to build an integrated sustainable hydropower assessment model based on checklist and SWOT analysis. The specific steps are shown in Figure 3. Firstly, to form, a structured checklist and evaluation criteria were set according to the project situation. Then, the current sustainable performance was evaluated by the checklist. The results of the current sustainability performance analysis are the basis for identifying the strengths and weaknesses of the project. Then, external opportunities and threats were identified. Finally, a SWOT analysis of the sustainable development of the project was formed.

3.2. Selection of Indicators. To fully understand the sustainable performance, Tajikistan needs to carry out sustainability assessments for hydropower projects. The sustainable assessment tool for hydropower projects that fits the national conditions is a prerequisite for a comprehensive and accurate evaluation of hydropower projects. Based on the general sustainable hydropower assessment, this study combined with Tajikistan's political, economic, and legal conditions to establish a sustainable assessment standard for hydropower projects in Tajikistan. These indicators can be divided into four aspects: economic, environmental, social, and risk management. 


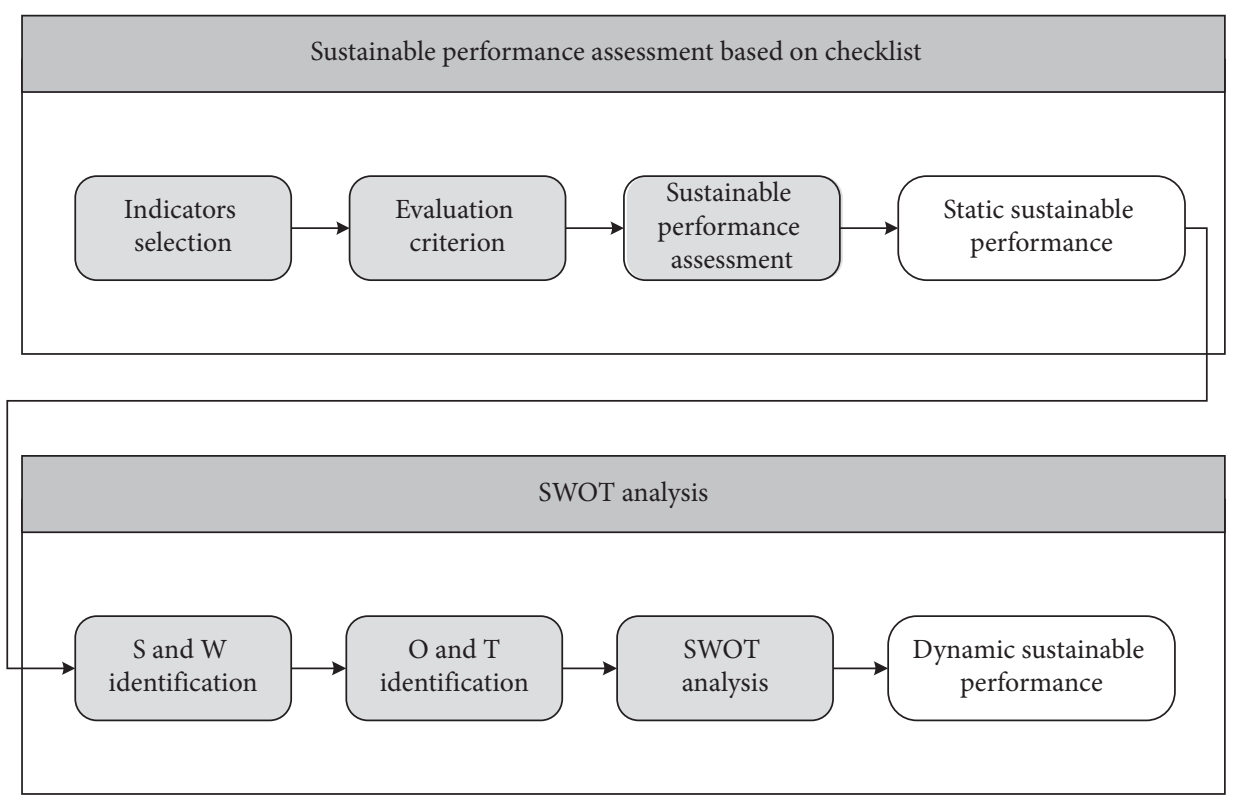

FIGURE 3: Conceptual framework of the integrated hydropower sustainability assessment.

\subsubsection{Environmental Aspect}

(1) Environmental Management Plan (EN1). Hydropower projects shall establish the environmental management system and implement relevant policies to meet legal requirements and other standards or policy requirements.

(2) Environment Impact Assessment (EN2). Environmental impact assessment (EIA) is essential for hydropower. In Tajikistan, the environmental impact assessment consists of two parts: (i) OVOS and (ii) state ecological expertise (SEE). The translation of OVOS into English appears as environmental impact assessment or EIA. In essence, OVOS is the material preparation stage, and SEE assumes a similar role as an environmental impact assessment. According to the domestic laws of Tajikistan, the new facilities and types of activities, which may have environmental impact, shall be made subject to OVOS and to mandatory SEE. This means that environmental impact assessments of hydropower projects must be carried out in Tajikistan. Also, the comprehensiveness and transparency of the content also should be included.

(3) Biodiversity (EN3). Poorly designed dams can cause irreversible damage to the environment [41]. To achieve environmental sustainability, plan should be made to reduce negative impacts on biodiversity and ecosystem.

(4) Pollution Prevention Measures (EN4). Hydropower projects should adopt pollution prevention and control measures to protect public health during construction and operation. Such as monitoring and controlling waste, noise, dust, air quality, water quality, and hazardous substances.

(5) Soil Erosion and Sedimentation (EN5). Tajikistan's hydropower stations are concentrated in the Vakhsh river basin which is characterized by high silt and sediment load.
The average turbidity of the Vakhsh river exceeds $4000 \mathrm{~g} / \mathrm{m}^{2}$. Sediment in the reservoir not only raises the water level, but also erodes turbine components and shortens the life of the power plant [42]. Tajikistan's largest Nurek hydropower, located in the Vakhsh river basin, is facing the challenge of high-load sedimentation. Once a large amount of sediment is deposited, it is difficult to clean up, so hydropower projects need to take measures to address soil erosion and sedimentation.

(6) Environmental Basic Flow Assessment (EN6). HPPs may disrupt the water cycle and cause downstream ecological degradation. International good practice shows that if the discharge volume and discharge period under sluices are arranged rationally, HPPs can maintain the basic ecological water demand of rivers and lakes and even bring positive effects to the downstream during the dry season. Considering that domestic agriculture and downstream agriculture are highly dependent on water resources, hydropower stations in Tajikistan must examine ecological flow and discharge flow.

\subsubsection{Economic Aspect}

(1) Project Economic Evaluation (EC1). Project economic analysis is indispensable in economic sustainability assessment. Net present value and sensitivity analysis are the key indicators.

(2) Financial Viability (EC2). The economic risks of the project, especially the rationality of fundraising, cannot be ignored in the sustainable assessment. The large dam projects rely on huge funds, so that the company's balance sheet and even the government's balance of payments account may be affected [11]. International Rivers [43] 
indicates that many hydropower projects are located in areas with high environmental and social risks because of the low environmental protection requirements, poor human rights protection, and corruption issues in their countries. Jadoon et al. [44] further point out if these countries are suffering from an energy shortage and financial crises, the sustainability performance of HPPs becomes even more serious, as financial pressures have led these countries to adopt cheaper but highly unsustainable solutions. Large dam infrastructure has also proved to be an economic burden for the government [45]. Since the collapse of the Soviet Union, the economic crisis and civil war have seriously damaged the country's national economy. Tajikistan's GDP in 2018 was $\$ 8.152$ billion, ranking 146 out of 196 economies and last among the five Central Asian countries [46]. It can be seen that Tajikistan's economic development is not only relatively backward in the world, but also in the five Central Asian countries. Therefore, the economic sustainability assessment of hydropower projects in Tajikistan should also focus on whether to pay all plans and commitments.

\subsubsection{Social Aspect}

(1) Resettlement (SO1). Dams often flood large areas of land, resulting in numerous involuntary resettlements. Involuntary resettlement may result in actual displacement (loss of land and residence) or economic displacement (loss of income source). Involuntary immigration is a special group that sacrifices personal interests for the benefit of the country. According to statistics, hydropower dams have forced more than 80 million involuntary resettlements and affected about 472 million people with negative impacts [47]. In the Republic of Tajikistan, the constitution stipulates that land belongs to the state. The land code allows the state to confiscate land from land users for the public interest. Regarding compensation for land requisition, according to Articles 41 and 43 of the Land Law, land can only be requisitioned if real estate, construction, and crops on the plot are equally compensated (and cannot be lower than the market price). Legal proceedings on involuntary resettlement are stipulated in the Civil Procedure Law and Economic Procedure Law of the Republic of Tajikistan. In general, the subsistence, fairness, and property rights of the affected people are protected by the laws of Tajikistan. Tajikistan is also committed to complying with World Bank policies on involuntary immigration [48].

(2) Social Impact Assessment (SO2). Both the World Bank and the Asian Development Bank regard the social assessment as a critical condition for loan approval. The social evaluation report analyzes the possible risks of the project through in-depth systematic investigation and research, proposing countermeasures to eliminate adverse effects, which has the important effect on improving the sustainability. The social evaluation of hydropower projects involves natural resources, project acceptability, social risk, compensation, and stakeholder participation.
(3) Communication and Negotiation (SO3). Large hydropower infrastructure needs to establish the communication and coordination mechanism, which facilitates stakeholders to express their demands and questions. At the same time, the project can also solve the disputes with stakeholders through this mechanism.

(4) Benefit Sharing (SO4). In some cases, hydropower projects have become a means for elites to grab resources and profits. However, communities affected by the project lose land even without sufficient compensation [22, 49, 50].

\subsubsection{Risk Management}

(1) Corruption (RI1). The risks of corruption need to be considered in hydropower sustainability assessments. The huge investments in dam infrastructure projects increase the risk of corruption [51]. According to international good practice, corruption risk assessment is the most cost-effective corruption prevention measure. It can identify potential corruption risks in advance and develop preventive measures. Corruption risk assessments are primarily concerned with whether policies are in place to mitigate corruption and whether the procurement process is fair and transparent.

(2) Transboundary River Governance (RI2). The crossborder rivers have sparked many political conflicts. In the Central Asian region, the management of transboundary water resources is related to regional stability and economic development. To obviate the fear of negative downstream impacts, Tajikistan must set up practical and feasible cross-border water resources management around the three core aspects, namely, fair distribution of water quantity, a guarantee of water quality, and ecological balance. Specifically, firstly, Tajikistan should strictly abide a series of water agreements among the five Central Asian countries. Secondly, Tajikistan needs to establish transparent monitoring system and maintain information exchange with other countries. Finally, it is import for the project to assess the cross-border impact and risk on the scale of the river basin

(3) Information Sharing (RI3). The project shall report risks to the affected communities on time, especially when environmental pollution accidents or other emergencies occur. Emergency measures must be taken promptly and properly. The residents who may be harmed by pollution shall be notified on time, and report to the local environmental protection administrative department shall be delivered immediately.

As shown in Table 1, 15 indicators with corresponding content were extracted from the literature review and finally formed a structural checklist for conducting hydropower sustainability assessment. These indicators were divided into economic, environmental, social, and risk management. The scope of the indicator is defined by the content, which helps assessors understand the tasks. 
TABLE 1: The checklist for hydropower sustainability assessment in Tajikistan.

\begin{tabular}{|c|c|c|c|}
\hline $\begin{array}{l}\text { Performance } \\
\text { indicators }\end{array}$ & & Content & References \\
\hline \multicolumn{4}{|c|}{ Economic aspect } \\
\hline EC1 & $\begin{array}{l}\text { Project economic } \\
\text { evaluation }\end{array}$ & $\begin{array}{l}\text { (i) Whether a wide range of factors has been considered, including } \\
\text { sensitivity analysis? } \\
\text { (ii) Whether to publicly disclose the results of economic viability analysis? } \\
\text { (iii) Whether the project has a net benefit? }\end{array}$ & {$[52]$} \\
\hline EC2 & Financial viability & $\begin{array}{l}\text { (i) Are the sources of project costs and benefits described in detail, } \\
\text { including risk assessment, scenario testing, and sensitivity analysis? } \\
\text { (ii) Whether the financing method is feasible? } \\
\text { (iii) Whether to pay for all plans and commitments, including social and } \\
\text { environmental aspects? } \\
\text { (iv) What is the impact of the project on the macroeconomy? }\end{array}$ & {$[44,52,53]$} \\
\hline \multicolumn{4}{|c|}{ Environmental aspect } \\
\hline EN1 & $\begin{array}{l}\text { Environmental } \\
\text { management plan }\end{array}$ & $\begin{array}{l}\text { (i) Has an environmental management plan been established? } \\
\text { (ii) Is the plan comprehensive? } \\
\text { (iii) Is it publicly available? }\end{array}$ & {$[29,54]$} \\
\hline EN2 & $\begin{array}{l}\text { Environment impact } \\
\text { assessment (EIA) }\end{array}$ & $\begin{array}{l}\text { (i) Whether the EIA is true and comprehensive? } \\
\text { (ii) Have local stakeholders been consulted? } \\
\text { (iii) Does the EIA establish alternatives (including no dam and multiple site } \\
\text { selection options)? } \\
\text { (iv) Is the EIA public or at least available? }\end{array}$ & [39] \\
\hline EN3 & Biodiversity & $\begin{array}{l}\text { (i) Does the project affect habitats with high biodiversity value? } \\
\text { (ii) Does the project have a plan to avoid or reduce impacts on biodiversity } \\
\text { and ecosystems? }\end{array}$ & {$[52,54]$} \\
\hline EN4 & $\begin{array}{l}\text { Pollution prevention } \\
\text { measures }\end{array}$ & $\begin{array}{l}\text { (i) Does the project have a management and monitoring plan? } \\
\text { (ii) What efforts have been made to avoid and reduce pollution? }\end{array}$ & {$[29]$} \\
\hline EN5 & $\begin{array}{l}\text { Soil erosion and } \\
\text { sedimentation }\end{array}$ & $\begin{array}{l}\text { (i) Does the project consider possible soil erosion and sedimentation } \\
\text { problems? } \\
\text { (ii) What measures have been implemented to deal with soil erosion and } \\
\text { sedimentation? }\end{array}$ & {$[39]$} \\
\hline EN6 & $\begin{array}{l}\text { Environmental basic flow } \\
\text { assessment }\end{array}$ & $\begin{array}{l}\text { (i) Has the project conducted an environmental basic flow assessment and } \\
\text { established a standard for discharge flow? }\end{array}$ & {$[39,52,55]$} \\
\hline Social aspect & & & \\
\hline
\end{tabular}

(i) Whether the resettlement complies with the principle of "compensation before placement?"

\begin{tabular}{|c|c|c|c|}
\hline SO1 & Resettlement & $\begin{array}{l}\text { (ii) Does the company adopt the principle of Free Prior Informed Consent } \\
\text { (FPIC)? } \\
\text { (iii) Does the resettlement improve living standards and provide } \\
\text { appropriate economic compensation? }\end{array}$ & {$[5,29,48]$} \\
\hline $\mathrm{SO} 2$ & $\begin{array}{l}\text { Social impact assessment } \\
\text { (SIA) }\end{array}$ & $\begin{array}{l}\text { (i) Is the SIA detailed and comprehensive? } \\
\text { (ii) Is the SIA consistent with the fact, and has it solicited opinions from } \\
\text { local stakeholders and regulators? }\end{array}$ & {$[56]$} \\
\hline $\mathrm{SO} 3$ & $\begin{array}{l}\text { Communication and } \\
\text { negotiation }\end{array}$ & $\begin{array}{l}\text { (i) Has the project established a communication and consultation system } \\
\text { with the local community? } \\
\text { (ii) How many public participation meetings have the project held? } \\
\text { (iii) Has a dispute and appeal mechanism been established? } \\
\text { (iv) How many major disputes have been reported and resolved through } \\
\text { the mechanism? }\end{array}$ & {$[54]$} \\
\hline $\mathrm{SO} 4$ & Benefit-sharing & $\begin{array}{l}\text { (i) Does the project have benefit-sharing other than one-time } \\
\text { compensation? }\end{array}$ & {$[2,22,29]$} \\
\hline \multicolumn{4}{|c|}{ Risk management } \\
\hline RI1 & Corruption & $\begin{array}{l}\text { (i) Are there policies to mitigate the risks of corruption? } \\
\text { (ii) Whether the procurement process is fair, transparent, and accountable? }\end{array}$ & {$[29,57]$} \\
\hline RI2 & $\begin{array}{l}\text { Transboundary river } \\
\text { governance }\end{array}$ & $\begin{array}{l}\text { (i) Does the project consider cross-border impacts? } \\
\text { (ii) Is there a monitoring and early warning system, and is information } \\
\text { exchange with upstream and downstream countries maintained? }\end{array}$ & {$[56,58,59]$} \\
\hline RI3 & Information sharing & $\begin{array}{l}\text { (i) Does the project regularly report to the community the most important } \\
\text { risks and opportunities? }\end{array}$ & {$[58]$} \\
\hline
\end{tabular}




\section{Case Study}

4.1. Case Background. The Rogun HPP is located in the central part of the Vakhsh river, with comprehensive benefits of irrigation, power generation, and flood control of largescale water conservancy, as shown in Figure 4. The multiyear average flow rate is $645 \mathrm{~m}^{3} / \mathrm{s}$, and the design flow rate is $5,750 \mathrm{~m}^{3} / \mathrm{s}$. The total reservoir capacity is 13 billion $\mathrm{m}^{3}$. The six $600,000 \mathrm{~kW}$ mixed-flow hydropower generating units will be installed, with a total installed capacity of 3.6 million $\mathrm{kW}$ and an annual generating capacity of 13.1 billion $\mathrm{kWh}$. A total investment of the US $\$ 2,198.7$ billion will be required for the completion and operation of the Rogun HPP.

Tajikistan conducted the first feasibility study and design for the construction of the Rogun project from 1965 to 1978. Construction preparations began in 1976, and construction of the main body of the project began in 1982. It was interrupted several times by the collapse of the Soviet Union, a blocked diversion tunnel, a Russian control dispute, and a lack of funds. On July 1, 2016, Tajikistan and Italian company Salini Impregilo agreed to cooperate for $\$ 3.9$ billion to continue the construction of the dam. The first unit of the HPP was connected to the grid in November 2018. The second hydropower unit completed and put into production in September 2019. All units are expected to be fully operational by 2024 . The main parameters of the phased development scheme of Rogun HPP are listed in Table 2.

The Rogun HPP can not only expand the power production, but also regulate the river flow, cut the peak, and fill the valley so as to guarantee the agricultural water and power supply in winter. When completed, the Rogun HPP will surpass the Nurek hydropower station to become the largest hydropower station in Central Asia. The Rogun HPP could completely fill the power gap in Tajikistan and be able to export power to other countries, which will greatly foster the economic development of Tajikistan. Because of the huge potential of the Rogun HPP, the elites strengthen the political propaganda and the sense of national identity and patriotism through the Rogun HPP. After the civil war of 1997-2001, President Emomali Rahmon began to instill new national consciousness in Tajikistan. The Rogun HPP has become an important symbol of progress, patriotism, and success. The project is also directly related to energy competition between Tajikistan and Uzbekistan. Uzbekistan has severely criticized the project and expressed concern about the reduction of downstream agricultural irrigation water. Eshchanov et al. [45] argue that the ambitious Rogun HPP will increase the budget deficit and shake the macroeconomic stability.

4.2. Sustainable Performance Assessment of Rogun Hydropower. A panel of 10 eminent hydropower experts in the design, construction, and operation was set up. According to the evaluation indexes listed above, they assessed the sustainable performance of Rogun HPP from four categories: economy, environment, society, and risk management. The purpose of this assessment was not to provide an overall score to judge whether the sustainability is acceptable, but to provide a systematic sustainability analysis report. However, to facilitate the discovery of advantages and disadvantages, each assessment theme will still be scored based on the implementation of the project to visually indicate the performance of each item. The scale of scoring is relative to Tajikistan's legal and policy requirements or basic good practice, not an acceptable level. When Tajikistan does not have a clear definition of the subject of an assessment, basic good practice will be referenced. Scores for each assessment topic range from 1 to 5 . Level 3 and Level 5 provide an important and clear scale for dividing the other scores. Level 3 describes basic good practices on a sustainability assessment topic. The specific meaning of basic good practice is consistent with the Hydropower Sustainability Assessment Protocol, namely, all projects should be working toward such practice, even in regions with the minimal resources or capacity. Level 5 describes best practices that have been proven in most national contexts for a sustainability problem. However, these best practices are not easily achieved. The specific scoring criteria are as follows:

(1) There are several significant gaps from basic good practices

(2) Most of the relevant elements are in place, but there is one significant difference from basic good practice

(3) Basic good practices that fully comply with the requirements of Tajikistan's legal and policy requirements or basic good practices

(4) Reach a level of basic good practice, but with one significant difference from best practice

(5) Proven best practices with no obvious need for improvement

The original score of the 10 experts are shown in Table 3 .

Next, the consistency of the data is checked. The individual ICC index was 0.711 , and the average ICC was 0.961 . The overall consistency of the data is verified. Therefore, the average score of the 10 experts is considered as the sustainability score of each indicator. The project's performances and a score of each indicator are presented in Table 4. At the same time, Figure 5 intuitively shows the sustainable performance of each indicator.

It can be seen from Table 4 that the index scores of four aspects of Rogun HPP are 2.05 for the economy, 3.31 for the environment, 1.76 for the society, and 1.79 for the risk management.

The score of environmental indicators is the highest. With high attention from the government of Tajikistan and the outside world, the preliminary feasibility study and environmental impact assessment of Rogun HPP are comprehensive and detailed. The advanced environmental protection technology has been employed in the Rogun HPP. It should be noted that the score of the biological diversity index (EN3) is 2, which is lower than the average level. Due to excessive investment in other parts, the government of Tajikistan lacks funds for biodiversity conservation.

The social indicators are all scored at 1.76 , indicating that the basic elements can be accomplished, but the gap still exists. The most prominent problem is involuntary 


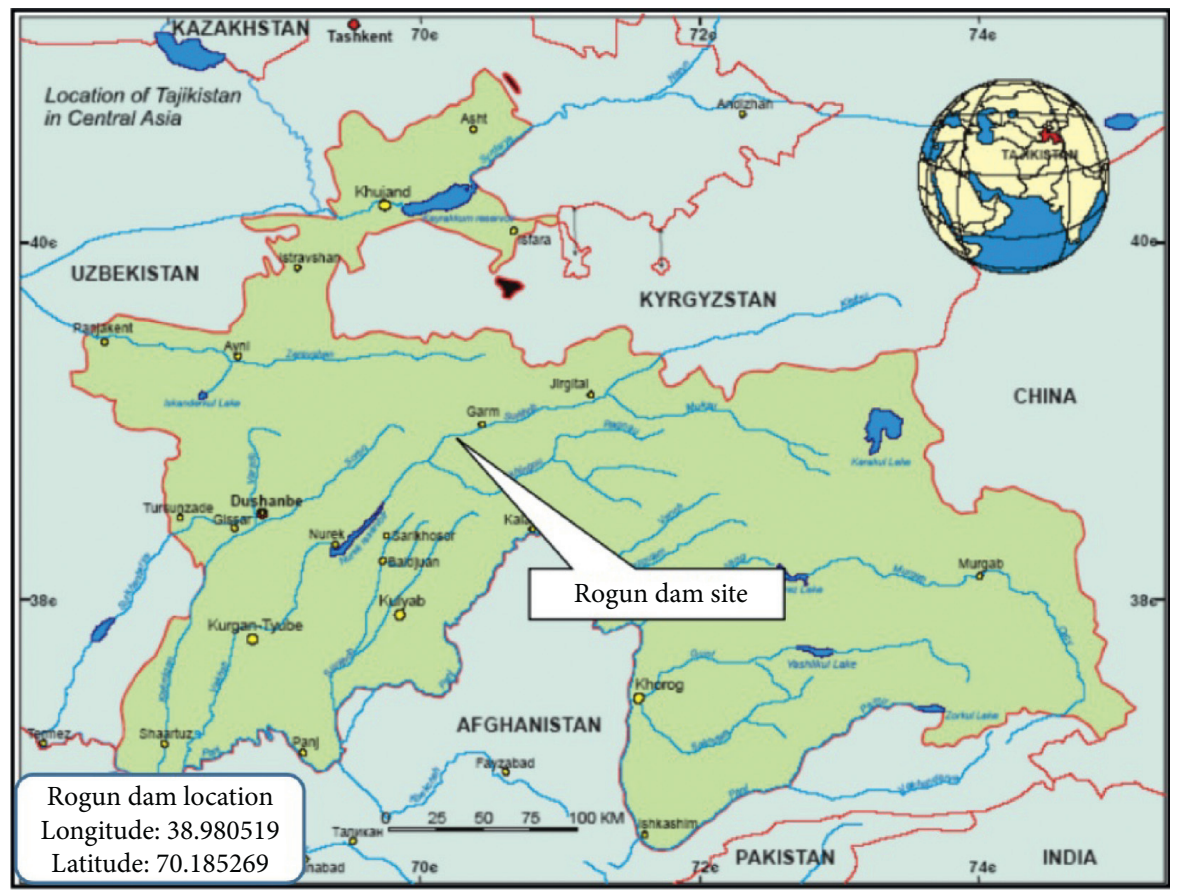

FIgURE 4: The location of Rogun HPP [56].

TABLE 2: Main parameters of the phased development scheme of Rogun HPP.

\begin{tabular}{|c|c|c|c|}
\hline$\underline{\text { Parameters }}$ & Phase 1 & Phase 2 & Phase 3 \\
\hline Height (m) & 225 & 285 & 335 \\
\hline Normal reservoir level $(\mathrm{m})$ & 1180 & 1240 & 1290 \\
\hline Minimum operating level (m) & 1120 & 1180 & 1230 \\
\hline Initial capacity $\left(\mathrm{km}^{3}\right)$ & 2.78 & 6.76 & 13.3 \\
\hline Initial effective capacity $\left(\mathrm{km}^{3}\right)$ & 1.92 & 3.98 & 10.3 \\
\hline Total installed (MW) & 1200 & 2400 & 3600 \\
\hline Installed unit number (pcs) & 3 & 4 & 6 \\
\hline Annual generating capacity (TWh) & 6.7 & 11.6 & 14.5 \\
\hline Vakhsh cascade increases annual power generation (TWh) & 0.4 & 0.9 & 1.2 \\
\hline
\end{tabular}

TABle 3: The original score of the 10 experts.

\begin{tabular}{|c|c|c|c|c|c|c|c|c|c|c|}
\hline \multirow{2}{*}{ Performance indicators } & \multicolumn{10}{|c|}{ Score } \\
\hline & Expert 1 & Expert 2 & Expert 3 & Expert 4 & Expert 5 & Expert 6 & Expert 7 & Expert 8 & Expert 9 & Expert 10 \\
\hline
\end{tabular}

\section{Economic aspect}

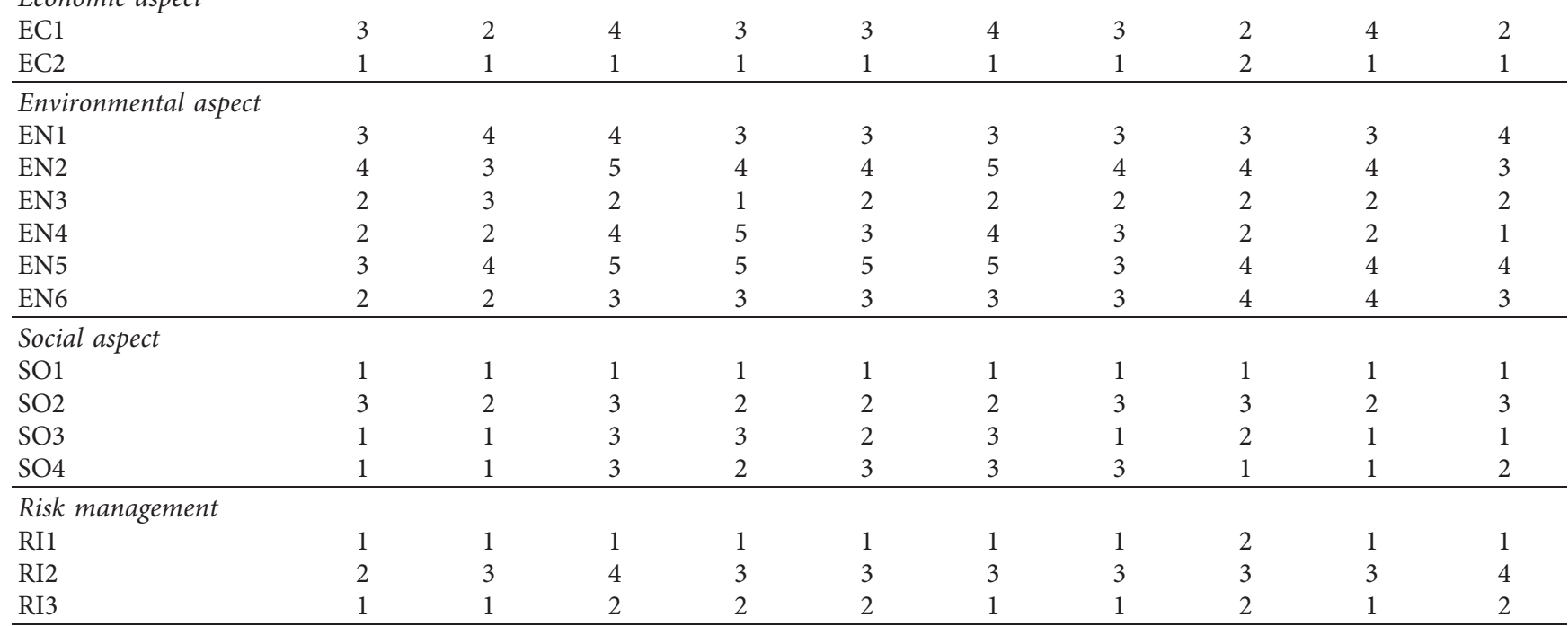


TABLE 4: The sustainability performance of Rogun HPP.

\begin{tabular}{|c|c|c|c|}
\hline Performance indicators & Project performance & Score & $\begin{array}{l}\text { Total } \\
\text { score }\end{array}$ \\
\hline Economic aspect & & & 2.05 \\
\hline
\end{tabular}

(i) At a discount rate of $8.5 \%$ for the Rogun project, the dynamic unit cost of the first phase project is 3.9 cents/kWh, which will be reduced

Economic evaluation (EC1) to 2.5 cents $/ \mathrm{kWh}$ if the two phases are developed together. The economic internal rate of return (IRR) is $11 \%$ for the first phase and $16 \%$ for both phases [60].

(ii) The projected budget of $\$ 2.5$ billion by May 2019 is exhausted. A total of 6 hydropower units need to be started, and one of them is successfully started $[60,61]$.

(i) The project has not been able to pay its promised payments on time. The Rogun HPP arrears over 5 months [62].

(ii) In 2018 and 2019, 18.3\% and 17\% of government public expenditure were used to support the construction of the Rogun HPP, respectively. In the third quarter of 2018, the financial allocation of the Rogun HPP pushed the fiscal deficit to $4.9 \%$ of GDP (World Bank Group, 2018).

(iii) In 2010, authorities raised $\$ 185$ million through an extensive publicity campaign to sell shares to the public, companies, and institutions. Forced share sales occur when more than $60 \%$ of the population lives below the official poverty line.

(iv) In 2010, the Rogun HPP was declared "the exclusive property of the state." The last request for financial assistance from the Tajikistan authorities to the World Bank for the construction of HPP was rejected.

(v) Masud Sobirov, a Tajikistan economist, also agrees that the government does not have the financial resources to complete the construction.

"The first and second batch of projects may start, but without attracting foreign investment and investors, the continued construction of projects will continue for many years, which will be a heavy burden for the national budget," Sobirov said [61].

Environmental aspect

Environmental management plan (EN1)

(i) A public environmental management plan has been established.

3.3

(i) The Rogun HPP carried out a detailed EIA by the

Environmental impact assessment (EN2) International Olympic Committee (IOC).

(ii) There are several site selection options.

(iii) The EIA results were released to the public.

(i) The first phase of the reservoir could flood $600 \mathrm{hm}^{2}$ farmland, a

Biodiversity (EN3) third of which is Arable land and the rest is pasture land [60].

(ii) Biodiversity is low and no important habitats or rare species are endangered.

Pollution control measures (EN4)

(i) Management and monitoring plans have been developed.

(i) Aiming at the problems of soil erosion and sediment deposition, the project adopted a series of protective measures in the diversion stage, including partial salt replacement. In addition, grouting curtain and

Soil erosion and sedimentation (EN5) water injection well are arranged to maintain the balance of return water volume, hydrogeology, and water chemistry ratio. After the completion of the project, the agency will also implement a wide range of grouting curtain [60].

(i) The total catchment area of the Vakhsh basin is about $39,000 \mathrm{~km}^{2}$.

About $30 \%$ of the catchment area is above $4,000 \mathrm{~m}$ above sea level and covered with snow and glaciers. Due to its mountainous

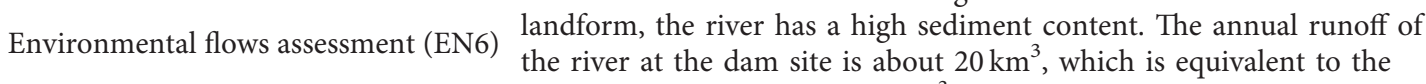

largely intact and unaffected by global climate change until at least 2050 [60]. 
TABLE 4: Continued.

\begin{tabular}{ll}
\hline Performance indicators & Project performance \\
\hline & (i) Local residents have a certain understanding of the project, \\
but the resettlement situation is not optimistic. In late May 2009, \\
Tajikistan authorities relocated the first 232 families from three villages \\
expected to flood the Rogun dam. More than 1,000 people from the Nurobod \\
district of the rocky Rasht valley were moved to Tangara, a cotton-growing \\
region in southern Tajikistan. Resettled people have neither the opportunity \\
to stay in their homelands nor the choice of where to move. \\
(ii) The Nurobod residents in flooded areas were forced to leave their homes. \\
The inhabitants of these mountain villages will reside in the Danghara, \\
Tursunzoda, and Faizobod valleys. The resettlement process is scheduled to \\
be completed by 2040. In the meantime, 42,000 people from 40 villages \\
will be moved elsewhere. The state has provided 200 million TJS \\
(about $\$ 19.4$ million) for the resettlement of the villagers. \\
(iii) The principle of "compensation before relocation" was not observed. \\
The living standards of those affected have declined significantly [63]. \\
(i) Before the construction of the first and second phases of the project, \\
social impact assessment has been conducted and released to the public. \\
(ii) The social impact assessment of the project conforms to factual information \\
and seeks advice from local stakeholders and regulatory authorities. \\
However, there are some differences between the social \\
influence performance and the research.
\end{tabular}

(i) The project did not hold a meeting involving the local public, and the opinions of the local residents could not be well reflected by the stakeholders and the local government.

Communication and negotiation (SO3) (ii) A certain level of communication and consultation has been established with the local community. In the first and second phases of the project, the contractor established a dispute appeal mechanism, but it did not play a good role [39].

Benefit sharing (SO4)

(i) The Rogun HPP mainly meets the domestic power demand and exports surplus power. Apart from meeting electricity demand and reducing electricity price, no benefit sharing is involved.

Risk management

(i) Low-quality cement, steel, and other building materials are used in the

Rogun HPP, according to the data from the Asia analysis platform.

(ii) No financial report has been published [62].

(iii) At a meeting of Rogun HPP's fund control committee in 2019,

Corruption (RI1) the panel of experts noted that the state's budget for construction and loan payments were particularly opaque.

(iv) Following a 2016 audit, the Agency for State Financial Control and anticorruption revealed 186 million Somalini (\$19.7 million) in funding shortfalls, registration irregularities, and other financial misconduct [61].

(i) The cross-border impact and risks of the project have been considered [39].

Transboundary river management (RI2)

Information sharing (RI3) (ii) Tajikistan signed specific agreements and established cooperation institutions [60].

(iii) Monitoring, early warning, and alarm systems have been established.

(iv) Upstream and downstream countries cannot exchange information.

(i) From early March to April 10, 2019, Tajikistan experienced severe power rationing throughout the country. The authorities did not report any information about the shutdown of the first reactor. There are rumors of leaks from the Rogun dam all over the country. The President fired the project's chief engineer on March $4^{\text {th }}$, further fueling rumors.

(ii) On March $4^{\text {th }} 2019$, an accident occurred at the Rogun HPP, forcing the managers in charge to pour water from the reservoir. Officials in charge of the field have not confirmed or disputed the information. (iii) Tajikistan economists and HPP stocks and funds control committee members Masud Sobirov pointed out that "He has not heard a report from the authorities about spending on HPP" [61]. 


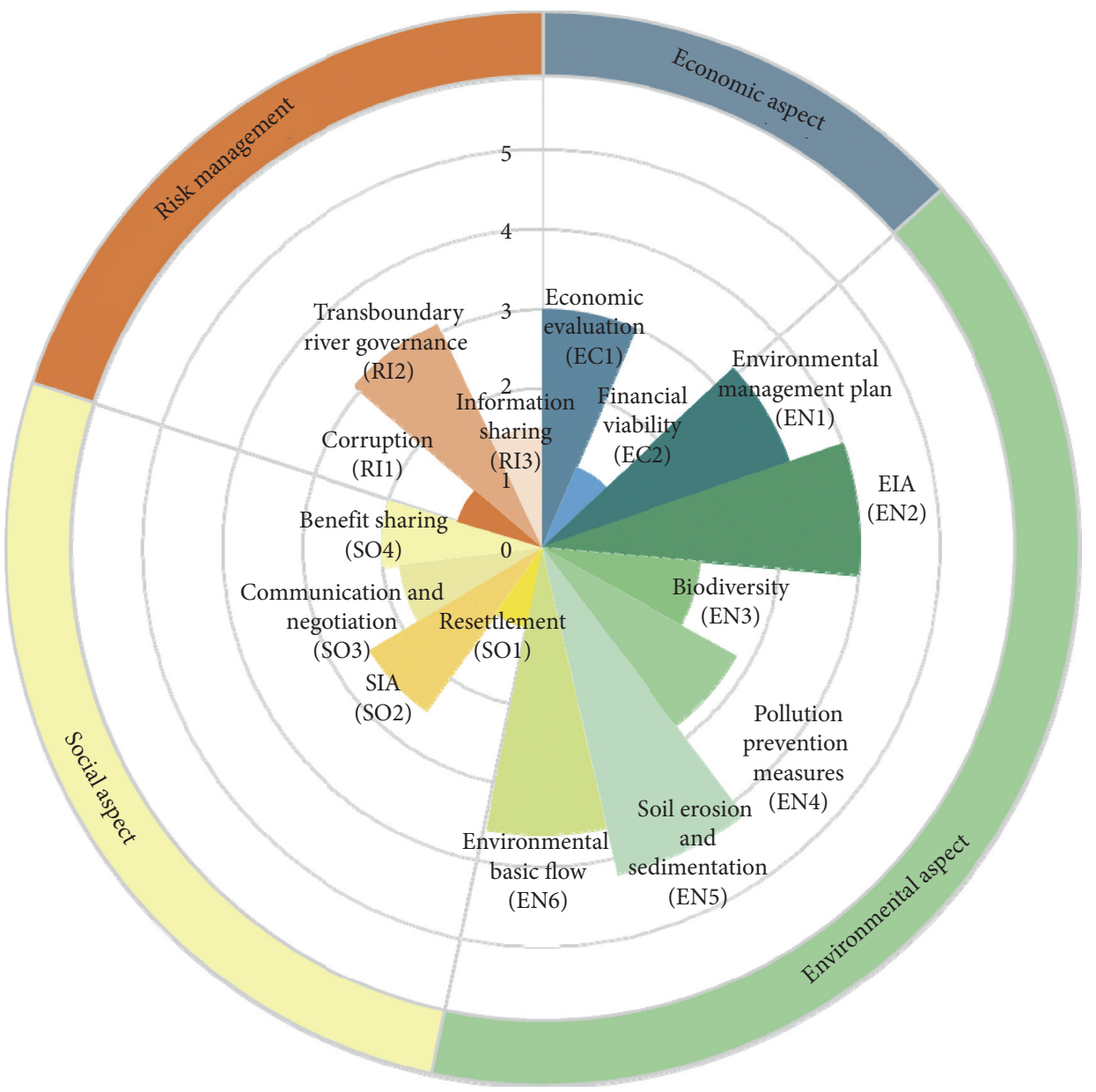

FIgURE 5: Sustainability assessment results of Rogun HPP.

resettlement. Many residents' resettlement residences are quite different from their original environment, and their living standards have declined dramatically. This also affects the score of social impact assessment (SO2). Before the construction of phase I and phase II projects, the social impact assessment has been completed and released to the public, but there is a big gap between the actual performance of involuntary resettlement and the assessment. Regarding communication and consultation (SO3), the website of the project and mainstream media are positive reports and political propaganda, while response to public doubts was lacking. The project team of Rogun HPP should draw lessons from other excellent resettlement practices. For example, the Bui hydropower project takes various measures to properly deal with the resettlement of migrants and the subsequent production and life. To expand agricultural production, improve the dam's catchment area, and improve food security across the country, the Bui project team envisions building a fishing port and launching an irrigation development plan of 30,000 hectares. The Chinese government, as a participant in the project, has agreed to buy 30,000 ton of Ghanaian cocoa from the day the dam began operating. This would create a huge market for cocoa production, which in turn would increase foreign exchange earnings and improve the livelihoods of cocoa farmers. At the same time, the project will benefit the society and promote the local economy by improving social infrastructure, such as roads, schools, and hospitals.

The average scores of economy and risk management were 2.05 and 1.79 , respectively. The economic evaluation (EC1) provided a detailed evaluation of the economic benefits. After the second stage, the IRR of the project reaches $16 \%$. But the financial viability (EC2) of the project is not sustainable. The salary arrears directly reflect the financial crisis of the project. Tajikistan was refused financial assistance from the World Bank, which directly increases the huge economic burden. The reasons for World Bank's rejection of Tajikistan's request for financial assistance were complicated, mainly because of water disputes between central Asian countries at the time and the energy dispute between the United States and Russia in central Asia. Moreover, the World Bank was not optimistic about Tajikistan's economic situation. It is important for Tajikistan to seek other funds to guarantee the construction of Rogun HPP. Risk management is another area that needs to be improved. Regarding the impact of Rogun HPP on downstream agriculture, Jalilov et al. [55] pointed out that the Rogun HPP will make agriculture in downstream countries 
receive a certain loss, such as Uzbekistan. In the future, the shortage of water resources will cause Uzbekistan's annual economic loss of more than $\$ 609$ million, while the GDP will drop by $2.2 \%$. The World Bank analyzes the downstream impact of Rogun HPP from a more comprehensive perspective. It states although the Rogun HPP may reduce the downstream water supply in the summer, it can guarantee the downstream water supply during the dry season [39]. Anyway, the dam should be accompanied by more open communication and cooperation with downstream countries to create a win-win situation. Corruption is particularly serious. The use of inferior materials, the opacity of capital expenditure, and the huge corruption all lead to the collapse of engineering quality. Because of the water disputes, Tajikistan and its downstream countries are in a prisoner's dilemma. Although River Management has assessed cross-border impacts and risks, upstream and downstream countries cannot exchange information. Information sharing (RI3) also urgently needs to be strengthened. The project expenditure report and project fault report were not published.

4.3. SWOT Analysis. The current sustainable performance has been evaluated by the checklist. Then the impact of external factors on the sustainability of the project was carried out through SWOT analysis, by which one can form a prediction of the future sustainability of the project.

4.3.1. Strengths. According to the results of the above project's sustainability performance, it can be concluded that the advantages of the project's sustainable development are comprehensive environmental assessment and environmental management plan, good environmental risk identification, and effective control measures.

Good environmental sustainability scores are due to the comprehensive and detailed environmental impact report of Rogun HPP. The environmental impact report of the Rogun HPP includes waste management, land management: soil conservation, erosion control, hazard management, and biodiversity, list of potential adverse environmental and social issues, Impact Assessment on Riparian countries of Rogun HPP, and hydrology and climate change impacts. Moreover, these reports are easily available online. To address the problems of soil erosion and silting, a series of appropriate protective measures were taken to maintain the hydrogeological balance.

\subsubsection{Weaknesses}

(1) Unsustainable Finance. The Central Asian Bureau for Analytical Reporting (CABAR) report states that most employees at Rogun HPP and its affiliates are facing unpaid salaries for five months [62]. The funding method of the Rogun HPP must be more diversified and robust. OJSC (Open Joint-Stock Company) Rogun HPP needs to strive to attract external investment, such as concessional loans, multilateral and commercial loans, and bonds. The authorities need to accelerate public financial reforms, improve the banking sector, and create a good investment environment to attract external investment and thereby achieve sustainable economy.

(2) Irregular Resettlement. The communities affected by the project have not received adequate compensation, and education, health care, and living standards have suffered a huge negative impact. In late May 2009, Tajikistan authorities relocated the first group of 232 families from three villages expected to flood the Rogun dam. More than 1,000 people from the rocky Nurabod district of the Rasht valley were transferred to the cotton-growing district of Danghara in southern Tajikistan. Resettled people have neither the opportunity to stay in their homeland nor the option to relocate.

(3) Blank Anticorruption Measures. At present, no effective anticorruption measures have been taken. President Rahmon stated in parliament's speech that "Compared to 2016, corruption among representatives of local authorities this year has increased by 25 percent" [64]. In the context of the high risk of corruption that Tajikistan is facing, the Rogun HPP with a total cost of about $\$ 3.9$ billion must crackdown on corruption. The project needs to strengthen financial transparency and strictly enforce public procurement laws. The financial reports need to be published to ensure the proper use of funds. To address the insufficient procurement process, the authorities also need to implement the electronic government procurement system as soon as possible to ensure fairness and transparency.

(4) Opaque Information System. The Rogun HPP also lacks the necessary information disclosure. Except for the World Bank report and the press release of Rogun HPP, no environmental and social risk warnings are announced on the website. The project company shall promptly report the environmental and social risks caused by the project to the community.

\subsubsection{Opportunities}

(1) The Belt and Road Initiative. In recent years, the Belt and Road Initiative has injected strong momentum into other developing countries in Asia. For example, The Chinese and Pakistani governments signed the "China-Pakistan Economic Corridor Energy Project Cooperation" agreement, dedicated to jointly tackle the shortage of power supply in Pakistan. Pakistan once faced a severe power shortage situation like Tajikistan, with a national power gap of 4500-5000 MW in 2012. The power gap has caused Pakistan's average annual GDP loss to reach \$ 13.5 billion. However, due to prolonged war, political instability, and lagging economic development, it is difficult for Pakistan to independently invest in large power projects. After the launch of the China-Pakistan Economic Corridor, China actively built a consultation platform among the 
government, financial institutions, and enterprises to enable the project to obtain sufficient funds. As of April 2019, energy projects under the framework of the China-Pakistan Economic Corridor have added 3,340 MW of electricity to Pakistan, accounting for $11 \%$ of Pakistan's total installed electricity capacity, which has greatly alleviated Pakistan's power shortage [65].

The Belt and Road Initiative is an opportunity for Tajikistan. China is actively assisting countries along the Belt and Road to address energy problems through financial assistance, technical assistance, and geopolitics. Firstly, the Chinese government is increasing loans to foreign governments [66]. The Export-Import Bank of China is becoming a major funding provider for large dams around the world. Tajikistan can make full use of the Belt and Road investment to ease the financial burden. Besides, China can provide new solutions to Tajikistan's sustainable hydropower development in water conservation, thermal power generation, and clean energy power generation. Chinese hydropower companies, such as China Water Conservancy and Hydropower Construction Corporation and China Power Construction Corporation Overseas Investment Co., Ltd., are rapidly growing into a leader in hydropower construction. It is estimated that the market share of China Power Construction Corporation Overseas Investment Co., Ltd., accounts for 50\%. Last but not least, the "community of common destiny for all mankind" can eliminate the barriers that restrict in the Central Asian region so that the five Central Asian countries can deepen cooperation with a more inclusive attitude. With China's increasing influence in Central Asia, China could provide constructive solutions for the Central Asia's water disputes.

(2) The Improving Business Environment. Tajikistan is improving the business environment through bank reform and informatization to attract foreign investment. Tajikistan was selected as one of the world's top ten business environment reformers in the Business Environment Report 2020 and has made significant progress in the fields of obtaining credit, developing new businesses, and promoting the export of commodities.

(3) The Detente with Uzbekistan. Emomali Rahmon emphasized that expanding cooperation with Central Asian countries is one of Tajikistan's foreign policy priorities. After Shavkat Mirziyaev is selected as President of the Republic of Uzbekistan, a positive trend towards the development of multilateral regional cooperation emerged. In 2018, Tajikistan and the Republic of Uzbekistan handled most of the sensitive issues during the past two decades. The strategic partnership has formed.

\subsubsection{Threats}

(1) Tightened Fiscal Appropriations. The Ministry of Energy and Water Resources of the Republic of Tajikistan established OJSC Rogun HPP with an authorized capital of 116 million TJS (about $\$ 11.3$ million) for the construction of Rogun HPP. OJSC Rogun HPP and Italian general HPP construction contractor Salini Impregilo SpA estimated the total cost of the project to be $\$ 3.9$ billion (approximately 40.2 billion TJS). Nearly 28 billion TJS (about $\$ 2.7$ billion) has been invested in the construction of Rogun HPP. The government's financial allocation is the main source of funds. In 2018 and 2019, 18.3\% and 17\% of government public expenditure were used to support the Rogun HPP, respectively. In the third quarter of 2018, the financial allocation of the Rogun HPP pushed the fiscal deficit to $4.9 \%$ of GDP [67]. In Tajikistan, the high proportion of public investment in the energy sector has led to cuts and delays of public expenditure in other sectors. Furthermore, the government of Tajikistan supports capital intensive energy projects, such as Rogun HPP, at the cost of the massive deficit, which increases the debt risk. According to the report from the World Bank [68], it is roughly estimated that the Rogun HPP still needs at least 19 billion TJS (about $\$ 1.8$ billion) to be put into operation. This means that Tajikistan will continue to face financial pressure from the Rogun HPP investments and growing debt service obligations. To alleviate the government's financial pressure and guarantee the construction of the Rogun HPP, the authorities of Tajikistan have tried other access to multichannel financing. In 2010, the authorities raised $\$ 185$ million through a wide publicity sale of shares to Tajikistan's public, companies, and institutions. Since more than $60 \%$ of the population was living below the official poverty line at the time, the sale of shares was not entirely voluntary. The World Bank advises authorities not to continue to force the sale of shares. In 2017 and 2018, the authorities raised $\$ 500$ million (about 5.1 billion TJS) for the Rogun HPP by selling government bonds on the European market. Nevertheless, government funding is still the major source of funding for the construction of the Rogun HPP in terms of financing scale. The World Bank Group [67] pointed out that Tajikistan's debt scale is at a relatively high level in the context of increasing public debt and further pressure to support the construction of Rogun HPP. To avoid the country's debt crisis, Tajikistan's budget law in 2019 stipulates fiscal consolidation, and the national budget deficit is reduced to 3\% of GDP. Besides, limited government deficits to the energy sector are also controlled. The government plans to increase budget allocations to the social sector (education, health, and social protection) and reduce expenditure in the energy sector, which may affect the financial viability of the Rogun HPP.

(2) Economic Downturn. During 2016-2019, although Tajikistan's GDP maintained a strong growth at $7 \%$, the World Bank predicts that Tajikistan's GDP will enter a turning point in 2020 because of Russia's economic downturn and the decline of international commodity prices. Tajikistan's GDP growth is expected to slow to about $5.5-5.0 \%$ in 2020-2021 [69]. A downward economy is usually accompanied by a decline in revenue.

(3) Resource Nationalism. Resource nationalism refers to a policy in which the state is increasingly strengthening its resource sovereignty, controlling its resource flow, and strengthening its resource value. The fundamental purpose is 
to strengthen the leading position of the government in the resource sector and increase the country's share in the distribution of resource benefits. In a public speech, President Rahmon said that he did not want to raise funds for the construction of Rogun HPP by selling shares on the international market because, in this case, the Rogun HPP will be influenced by foreign countries, which will contradict the interests of the people. This speech hoped to accelerate the fundraising process by stimulating domestic resource nationalism. Resource nationalism has made some Tajik elites exclude foreign companies from participating in the development and use of their own energy.

(4) The Game between Powers. Besides, the Game between Powers has also affected the deep cooperation between China and Tajikistan. Since the independence of Central Asian countries, Central Asia has become the new venue for the game between the United States, Russia, and China. After the war in Afghanistan, American influence has declined, while China and Russia's influence has continued to rise. The foreign policy of the five Central Asian countries has gradually formed a pattern that economic development relies on China, while security protection mainly relies on the Russian-led Commonwealth of Independent States (CIS) collective security treaty organization. As the economic and trade relations between China and Tajikistan continue to deepen, Tajikistan's economic dependence on China has increased. Tajikistan and Russia maintain high levels of security cooperation, but economic cooperation has not made significant progress. With the fear of losing part of its political and economic sovereignty, Tajikistan has a waitand-see attitude towards joining the Eurasian Economic Union dominated by Russia. The economic crisis in Russia and China's One Belt One Road objectively weakened the expectations of Central Asian countries for Russian economic cooperation. But Tajikistan is still hesitating between the two.

(5) High Corruption Rate. The corruption rate in Tajikistan is high. The President of Tajikistan mentioned that "corruption by local government representatives has increased by $25 \%$ this year (2017) compared with 2016" [64]. The high rate of corruption in Tajikistan is an important reason for the lack of anticorruption measures in the Rogun HPP and the lack of transparency in financial information.

\section{Discussion}

It is expected that construction and filling of the Rogun HPP will take more than 15 years. The construction cycle is so long that the sustainable performance of the project is bound to change over time. Therefore, it is necessary to integrate static and dynamic perspectives for sustainable evaluation. From the static perspective, the environmental sustainability of Rogun HPP is superior to economic sustainability and social sustainability. The Rogun HPP needs to improve its sustainability in financial viability, compensation and resettlement, corruption, and information disclosure. From the dynamic perspective, although preliminary environmental and social management plans have been developed for the project, they still need to be constantly updated to make them more specific for implementation. Moreover, current water allocation mechanisms and practices appear to be feasible and satisfactory to all parties in the current situation. In the long term, current allocations may not be sustainable as central Asian countries increasing demand for water. In the future, central Asian countries should reach consensus on water sharing as soon as possible and sign clear, understandable, transparent, monitored, and enforceable water agreements.

The Rogun HPP is not a simple small hydropower project. Identifying external opportunities and challenges can help the project management team to analyze the dynamic change trend of sustainable performance and improve the sustainability of Rogun HPP with the help of external resources. Based on the above analysis, the strengths, weaknesses, opportunities, and threats for the sustainable development of the Rogun HPP are listed in Table 5. It can be seen from Table 5 that good performance in the environmental aspect has not been threatened or enhanced by external factors. At the same time, the weaknesses are faced with both opportunities and threats:

Weaknesses and opportunities (WO): the Belt and Road initiative, improved business environment, and easing relations between Tajikistan and Uzbekistan are opportunities for sustainable development of Rogun HPP. Firstly, the Belt and Road initiative can provide the most urgent financial assistance for the project. Secondly, gradually improving business environment is conducive to attracting foreign investment. Finally, easing relations between Tajikistan and Uzbekistan will play a positive effect on the transboundary water resource information monitoring and sharing.

Weaknesses and threats (WT): the threats to sustainable development include tight fiscal allocation, expected GDP decline, resource nationalism, and the Game Between Powers. The tight financial allocation and expected GDP decline will aggravate the financial risk of the project. If the source of funds is not guaranteed, it will be more difficult to ensure that the involuntary resettlement will get adequate compensation. Attracting foreign investment is the most effective way to solve the current financial issues. But resource nationalism and the Game between Powers are obstacles to attracting foreign investment

The Rogun HPP should have a clear understanding of the current sustainable performance and the possible positive or negative impact of external factors on hydropower sustainability. Then Rogun HPP needs to take full advantage of the external opportunities to eliminate the current weaknesses and take measures to avoid the negative impact of external threats on sustainable development. 
TABLE 5: SWOT matrix for sustainable development of Rogun HPP. $\mathrm{S}$

(i) Comprehensive environmental assessment and environmental management plan

(ii) Good environmental risk identification and effective measures W

(i) Unsustainable finance/highly dependent on financial allocation

(ii) Irregular resettlement

(iii) Blank anticorruption measures

(iv) Opaque information system

$\mathrm{O}$

(i) The Belt and Road initiative

(ii) Improving business environment

(iii) The detente with Uzbekistan

$\mathrm{T}$

(i) Tightened fiscal appropriations

(ii) Resource nationalism

(iii) The game between powers

(iv) Economic downturn

(v) High corruption rate

\section{Conclusions}

The purpose of this study was to explore the current sustainable performance of the Rogun HPP and the potential change in sustainability in the future. By conducting a comprehensive literature review, a checklist of 15 indicators that conform to the situation in Tajikistan was identified. Compared with the implementation performance of Rogun HPP and good practice, it is found that the project is facing financial issue, irregular resettlement, blank anticorruption measures, and opaque information system currently. When considering the impact of external factors on the sustainability in the integrated framework, it should be noted that external threats such as tight fiscal allocations and economic downturns could further reduce sustainability. At the same time, Tajikistan can seize opportunities such as the Belt and Road initiative and improve business environment to attract foreign investment, thereby solving the urgent financial issues. Besides, Tajikistan can take advantage of detente with Uzbekistan to enhance information sharing and benefit sharing, thus easing water disputes. This paper proposed an integrated model to assess the sustainability of hydropower projects, namely, considering both the static performance and the future changes.

Although the objectives of this study were achieved, some limitations were still present. First, the sustainability assessment in the model was based on a literature review. The field investigation cannot be carried out due to geographical restrictions. Therefore, the gap between some policy expectations and actual performance may not be discovered and indicated. To increase the accuracy and reliability of the evaluation results, an expert group was established. They scored the sustainable performance of the project based on the basic material of the Rogun HPP and their own rich experience. Also, the index listed in the evaluation model considered in this article may not cover all aspects, such as local political stability which they may beyond the control of project managers. Lastly, the purpose of this paper is to present the sustainable performance of each indicator, so the weight is not calculated. In the future, more exploration can be made in the weight of indicators. Nonetheless, the results of this research are still valuable for decisionmakers to have a more comprehensive understanding of hydropower projects and make full use of external resources to strengthen sustainability and reduce the negative environmental, social, and economic impacts. Furthermore, the checklist could be moved to other hydropower projects.

\section{Data Availability}

The data used to support the findings of this study are available from the corresponding author upon request.

\section{Conflicts of Interest}

The authors declare that there are no conflicts of interest regarding the publication of this paper.

\section{Acknowledgments}

The authors specially thank all survey participants and acknowledge the Ministry of Education of Humanities and Social Science Project in China, under grant no. 20YJAZH114.

\section{References}

[1] G. W. Frey and D. M. Linke, "Hydropower as a renewable and sustainable energy resource meeting global energy challenges in a reasonable way," Energy Policy, vol. 30, no. 14, pp. 1261-1265, 2002.

[2] K. J. Hancock and B. K. Sovacool, "International political economy and renewable energy: hydroelectric power and the resource curse," International Studies Review, vol. 20, no. 4, pp. 615-632, 2018.

[3] "Re-powering markets: market design and regulation during the transition to low-carbon power systems," International Energy Agency, vol. 109, no. 10, pp. 1275-1255, 2016.

[4] B. K. Sovacool and G. Walter, "Major hydropower states, sustainable development, and energy security: insights from a preliminary cross-comparative assessment," Energy, vol. 142, pp. 1074-1082, 2018.

[5] X. Zhao, L. Wu, and Y. Qi, "The energy injustice of hydropower: development, resettlement, and social exclusion at the Hongjiang and Wanmipo hydropower stations in China," Energy Research \& Social Science, vol. 62, 2020.

[6] C. Zarfl, A. E. Lumsdon, J. Berlekamp, L. Tydecks, and K. Tockner, "A global boom in hydropower dam construction," Aquatic Sciences, vol. 77, no. 1, pp. 161-170, 2015.

[7] World Commission on Dams, Dams and Development: A New Framework, World Commission on Dams, London, UK, 2001.

[8] E. F. Moran, M. C. Lopez, N. Moore, N. Müller, and D. W. Hyndman, "Sustainable hydropower in the 21 st century," Proceedings of the National Academy of Sciences, vol. 115, no. 47, pp. 11891-11898, 2018.

[9] C. A. Scott, S. A. Pierce, M. J. Pasqualetti, A. L. Jones, B. E. Montz, and J. H. Hoover, "Policy and institutional dimensions of the water-energy nexus," Energy Policy, vol. 39, no. 10 , pp. 6622-6630, 2011.

[10] J. E. Oconnor, J. J. Duda, and G. E. Grant, "1000 dams down and counting," Science, vol. 348, no. 6234, pp. 496-497, 2015. 
[11] A. Ansar, B. Flyvbjerg, A. Budzier, and D. Lunn, "Should we build more large dams? The actual costs of hydropower megaproject development," Energy Policy, vol. 69, pp. 43-56, 2014.

[12] B. Terminski, Development-Induced Displacement and Resettlement, Theoretical Frameworks and Current Challenges, University of Geneva, Geneva, Switzerland, 2013.

[13] J. Kirchherr, M.-P. Ahrenshop, and K. Charles, "Resettlement lies: suggestive evidence from 29 large dam projects," World Development, vol. 114, pp. 208-219, 2019.

[14] F. P. Miller, A. F. Vandome, and J. Mcbrewster, "Global corruption report 2007," Transparency International, Berlin, Germany, 2007.

[15] C. S. Greacen and C. Greacen, "Thailand's electricity reforms: privatization of benefits and socialization of costs and risks," Pacific Affairs, vol. 77, no. 3, pp. 517-541, 2004.

[16] A. Simpson, "The environment-energy security nexus: critical analysis of an energy "love triangle" in Southeast Asia," Third World Quarterly, vol. 28, no. 3, pp. 539-554, 2007.

[17] I. Yüksel, "Dams and hydropower for sustainable development," Energy Sources, Part B: Economics, Planning, and Policy, vol. 4, no. 1, pp. 100-110, 2009.

[18] S. M. Born, K. D. Genskow, T. L. Filbert, N. Hernandez-Mora, M. L. Keefer, and K. A. White, "Socioeconomic and institutional dimensions of dam removals: the Wisconsin experience," Environmental Management, vol. 22, no. 3, pp. 359-370, 1998.

[19] WWF, Biggest Dam Removal in European History Begins, 2019.

[20] K. Bakker, "Contested waterscapes in the Mekong region: hydropower, livelihoods and governance," Mountain Research and Development, vol. 30, no. 4, pp. 407-408, 2010.

[21] S. W. D. Pearse-smith, "The impact of continued Mekong basin hydropower development on local livelihoods," Consilience: Journal of Sustainable Development, vol. 7, pp. 73-86, 2012.

[22] N. Matthews, "Water grabbing in the Mekong basin e an analysis of the winners and losers of Thailand's hydropower development in Lao PDR," Water Alternatives, vol. 5, no. 2, pp. 392-411, 2012.

[23] S. Jusi, "The Asian development bank and the case study of the Theun-Hinboun hydropower project in Lao PDR," Water Policy, vol. 8, no. 5, pp. 371-394, 2006.

[24] UNIDO, "World small hydropower development report," UNIDO, Vienna, Austria, 2013.

[25] ADB, Assessment of the Energy Sector of Tajikistan, ADB, Mandaluyong, Philippines, 2013.

[26] ADB, "Tajikistan power sector development master plan final report," ADB, Metro Manila, Philippines, 2017.

[27] Energy Charter Secretariat, Tajikistan: In-Depth Energy Efficiency Review, Copenhagen Centre on Energy Efficiency, Copenhagen, Denmark, 2013.

[28] T. Gulov, Water Governance in the OSCE Area - Increasing Security and Stability through Co-operation Russia, Organization for Security and Co-operation in Europe, Vienna, Austria, 2015.

[29] IHA, "Hydropower status report," IHA, London, UK, 2019.

[30] IEA, World Energy Balances, IEA, Paris, France, 2019.

[31] World Bank, World Bank Supports Rehabilitation of the Nurek Hydro Power Plant in Tajikistan, World Bank, Washington, DC, USA, 2019.

[32] Z. J. Li, L. Li, Y. Zhou, Y. F. Guo, and F. M. Ye, "Analysis and solution of power shortage in low flow period in Tajikistan," Design of Hydropower Station, vol. 35, no. 3, pp. 52-56, 2019.

[33] IEA, Sustainable Energy for All, IEA, Paris, France, 2013.
[34] CASA-1000, The Long-Term Plan, 2019.

[35] G. He, "The future of China's hydropower: accelerating development and sustainable development," Water Power, vol. 12, pp. 23-27, 2004.

[36] A. Roinioti and C. Koroneos, "Integrated life cycle sustainability assessment of the Greek interconnected electricity system," Sustainable Energy Technologies and Assessments, vol. 32, pp. 29-46, 2019.

[37] F. M. Turan and K. Johan, "Systematic sustainability assessment (SSA) tool for hydroelectric project in Malaysia," IOP Conference Series: Materials Science and Engineering, vol. 226, Article ID 012051, 2017.

[38] S. Ito, S. E. Khatib, and M. Nakayama, "Conflict over a hydropower plant project between Tajikistan and Uzbekistan," International Journal of Water Resources Development, vol. 32, no. 5, pp. 692-707, 2016.

[39] World Bank, "Final report of the environmental and social panel of experts," World Bank, Washington, DC, USA, 2014.

[40] M. I. Khan, "Evaluating the strategies of compressed natural gas industry using an integrated SWOT and MCDM approach," Journal of Cleaner Production, vol. 172, pp. 10351052, 2018.

[41] J. Sarkkula, M. Keskinen, J. Koponen, M. Kummu, and O. Varis, Hydropower in the Mekong Region: What Are the Likely Impacts upon Fisheries?, Earthscan, London, UK, 2009.

[42] B. Thapa, R. Shrestha, P. Dhakal, and B. S. Thapa, "Problems of Nepalese hydropower projects due to suspended sediments," Aquatic Ecosystem Health \& Management, vol. 8, no. 3, pp. 251-257, 2005.

[43] The International Rivers, A Guide on China's Overseas Dam Industry, The International Rivers, Berkeley, CA, USA, 2012.

[44] T. R. Jadoon, M. K. Ali, S. Hussain, A. Wasim, and M. Jahanzaib, "Sustaining power production in hydropower stations of developing countries," Sustainable Energy Technologies and Assessments, vol. 37, 2020.

[45] B. R. Eshchanov, M. G. P. Stultjes, S. K. Salaev, and R. A. Eshchanov, "Rogun dam-path to energy independence or security threat?" Sustainability, vol. 3, no. 9, pp. 1573-1592, 2011.

[46] IMF, World Economic Outlook Database, IMF, Washington, DC, USA, 2019.

[47] B. D. Richter, "Lost in development's shadow: the downstream human consequences of dams," Water Alternatives, vol. 3, no. 2, pp. 14-42, 2010.

[48] World Bank, Resettlement Policy Framework, World Bank, Washington, DC, USA, 2019.

[49] H. M. Mathur, "The future of large dams: dealing with social, environmental, institutional and political costs," Hydro Nepal Journal of Water Energy \& Environment, vol. 2, no. 4, pp. 1117-1119, 2008.

[50] D. Magee, "Powershed politics: yunnan hydropower under great western development," The China Quarterly, vol. 185, pp. 23-41, 2006.

[51] C. Kenny, Infrastructure Governance and Corruption: Where Next?, World Bank, Washington, DC, USA, 2007.

[52] IHA, Hydropower Sustainability Assessment Protocol, IHA, London, UK, 2010.

[53] S. Jusi, "Hydropower and sustainable development: a case study of Lao PDR," in Proceedings of the Environmental Economics and Investment Assessment III, Ashurst, UK, April 2010.

[54] The International Rivers, Benchmarking the Policies and Practices of International Hydropower Companies-Part A: Methodology and Analysis, The International Rivers, Berkeley, CA, USA, 2015. 
[55] S.-M. Jalilov, M. Keskinen, O. Varis, S. Amer, and F. A. Ward, "Managing the water-energy-food nexus: gains and losses from new water development in Amu Darya river basin," Journal of Hydrology, vol. 539, pp. 648-661, 2016.

[56] World Bank, Key Issues for Consideration on Proposed Rogun Hydropower Project, World Bank, Washington, DC, USA, 2014.

[57] Anti-Corruption Resource Centre, Grand Designs: Corruption Risks in Major Water Infrastructure Projects, Anti-Corruption Resource Centre, Bergen, Norway, 2009.

[58] K. Wegerich, O. Olsson, and J. Froebrich, "Reliving the past in a changed environment: hydropower ambitions, opportunities and constraints in Tajikistan," Energy Policy, vol. 35, no. 7, pp. 3815-3825, 2007.

[59] D. Karthe, S. Chalov, and D. Borchardt, "Water resources and their management in central Asia in the early twenty first century: status, challenges and future prospects," Environmental Earth Sciences, vol. 73, no. 2, pp. 487-499, 2014.

[60] R. Schwart and X. H. Zhu, "Feasibility study of the completion of the first phase of the Rogong project in Tajikistan," Express of Water Resources and Hydropowe, vol. 3, pp. 7-10, 2008.

[61] S. Ahmadzai and A. McKinna, "Afghanistan electrical energy and trans-boundary water systems analyses: challenges and opportunities," Energy Reports, vol. 4, pp. 435-469, 2018.

[62] CABAR and H. P. P. Rogun, "Financial problems, accident and non-transparency," 2019.

[63] HRW, The Rights Violations Linked Resettlements in Tajikistan, HRW, New York, NY, USA, 2014.

[64] E. Rahmon, The President of the Republic of Tajikistan, The Leader of the Nation, Emomali Rahmon, Address to the Majlisi Oli of the Republic of Tajikistan, 2017.

[65] M. S. Tang, "One belt, one road flagship and benchmarking in the China Brazil economic corridor," New Silk Road Horizon, vol. 11, pp. 43-47, 2016.

[66] C. S. Jensen and W. Down, How Do Big Hydropower Companies Adhere to Social and Environmental Policies and Best Practices?, International Rivers, Auckland, CA, USA, 2019.

[67] World Bank Group, Tajikistan: Rogun HPP-Potential Resource for Building Human Capital, World Bank Group, Washington, DC, USA, 2018.

[68] World Bank, Techno-Economic Assessment Study for Rogun Hydroelectric Construction Project, World Bank, Washington, DC, USA, 2014.

[69] World Bank and Tajikistan, Country Economic Update-Fall 2019, World Bank, Washington, DC, USA, 2019. 